\title{
Yield and quality of 'gália' melon grown in coconut fiber under different concentrations of macronutrients in the nutrient solution
}

\author{
Producción y calidad de melón cultivado en fibra de coco bajo diferentes \\ concentraciones de macronutrientes en solución nutritiva \\ Christiano Rebouças Cosme ${ }^{1}$, Nildo da Silva Dias ${ }^{1}$, Karen Mariany Pereira Silva ${ }^{1}$, \\ Camilo Vinícius Trindade Silva1, Ítalo Sorac Rafael de Queiroz', Tainan Costa Rebouças ${ }^{1}$ \\ and Cleyton dos Santos Fernandes ${ }^{1}$
}

\begin{abstract}
The cultivation of the 'Gália' netted melon in hydroponic systems under protected conditions has increased recently. However, the information on nutrient solutions for melon soilless cultivation is still very generalized, which requires studies adapted to the local conditions and the large existing variety of cultivars. With the objective of evaluating the effects of different concentrations of macronutrients in the nutrient solution on the production and quality of 'Gália' melon (Cucumis melo L., hybrid 'Babilônia RZ F1') grown in substrate of coconut fiber, an experiment was conducted in randomized blocks, with five treatments and five replicates. The treatments, concentrations of macronutrients in the nutrient solution, were based on the standard solution recommended by the literature (100\%) and the others were obtained from dilutions of this standard solution in tap water (75, 50, 25 and $12.5 \%)$. The analyses of the results showed that the variables mean fruit weight, longitudinal diameter and transverse diameter were quadratically influenced by the concentrations of the nutrient solution. The concentration of $47 \%$ led to the highest mean fruit weight. The increase in the concentration of the solution reduced the content of soluble solids of the fruit by $11.8 \%$.
\end{abstract}

Key words: Cucumis melo L, soilless cultivation, substrate.

\section{RESUMEN}

Últimamente, viene creciendo el cultivo de melón reticulado tipo Galia en sistema hidropónico bajo condiciones de cultivo protegido. Sin embargo, las informaciones sobre soluciones nutritivas para el cultivo sin suelo en melón, todavía son muy generalizadas, habiendo necesidad de estudios adaptados a las condiciones locales y a la gran variedad de cultivares existentes. Con el objetivo de evaluar los efectos de diferentes concentraciones de macronutrientes en la solución nutritiva en la producción y calidad del melón Galia (Cucumis melo L., híbrido Babilonia RZ F1) cultivado en sustrato de fibra de coco, se género un experimento conducido en delineamiento de bloques al azar, siendo este de cinco tratamientos y cinco repeticiones. Los tratamentos, concentraciones de macronutrientes en la solución nutritiva, se basaron en la solución estándar recomendada por la literatura (100\%) y, los demás, obtenidos a partir de diluciones de esta solución estándar en agua del grifo (75, 50, 25 y 12,5\%). Los análisis de los resultados mostraron que las variables peso medio de frutos, diámetro longitudinal y diâmetro transversal fueron cuadraticamente influenciadas por las concentraciones de la solución nutritiva. La concentración del $47 \%$ condujo al mayor peso medio de los frutos. El aumento de la concentración de la solución redujo en un 11,8\% el contenido de sólidos solubles del fruto.

Palabras clave: Cucumis melo L, cultivo sin suelo, sustrato.

\section{Introduction}

The melon crop has great economic importance in the northeast region; the state of Rio Grande do Norte is the largest melon producer in Brazil, achieving a production of $232,575 \mathrm{t}$ in 2014 , which corresponds to $39.42 \%$ of the Brazilian production (IBGE, 2014). The noble melon cultivars such as those in the 'Gália' and 'Cantaloupe' groups increased their participation in the market in recent years (Damasceno et al., 2012). However, these cultivars are more sensitive, requiring more advanced cultivation techniques (Medeiros et al., 2011), and it is necessary to conduct studies on techniques that improve and increase the yield of these new cultivars.

The success in vegetable production depends on information about the production systems,

\footnotetext{
1 Agricultural science center, Federal Rural University of the Semi-Arid, Mossoró, Rio Grande do Norte, Brazil.

* Corresponding author: cleyton1959@hotmail.com
}

Fecha de Recepción: 4 Julio, 2017.

Fecha de Aceptación: 29 Octubre, 2017. 
management and especially nutrition (Furlani et al., 1999). According to Dias et al. (2006), the success of hydroponic cultivation systems is associated with the balanced application of the nutrient solution, and in the case of melons there has been a positive response regarding the effects of the nutrient solution, resulting in the increase of yield and quality of the fruits.

It has been common to use coconut husk fiber as a growing medium for the plant, a renewable and ecologically correct substrate, with the aim of allowing cultivation in areas with soil contamination problems and favoring the production (Cardoso et al., 2009). Coconut fiber has been recommended as substrate of open hydroponic cultivation systems to attenuate the effects of the high salinity of the nutrient solution on the melon plants (Dias et al., 2011). It is also important to consider the relevance of using organic residues in agriculture, which through modern production techniques aims to increase yield and mitigate adverse environmental impacts.

Considering the necessity of more specific studies on the fertilization for each species associated with the production system and with the local climate conditions, this study aimed to evaluate the effects of applying different concentrations of macronutrients in the nutrient solution on the production and quality of 'Gália' melon grown in coconut fiber in the region of Mossoró-RN, Brazil.

\section{Material and methods}

The experiment was carried out from February to May 2015 in a protected environment of the Department of Environmental and Technological Sciences of the Federal Rural University of the Semi-Arid, located in the municipality of MossoróRN, Brazil (5'11' S; $37^{\circ} 20^{\prime} \mathrm{W}$ at $18 \mathrm{~m}$ altitude).

The protected environment was composed of an arched cover, $6.4 \mathrm{~m}$ wide and $18 \mathrm{~m}$ long with ceiling height of $3.0 \mathrm{~m}$, covered with low-density polyethylene film with anti-ultraviolet additive and thickness of $150 \mu \mathrm{m}$, protected on the sides with $50 \%$ black screen.

A weather station (Irriplus E500) was installed to monitor the microclimate of the cultivation environment, recording temperature and relative humidity daily (Figure 1 and Figure 2, respectively).

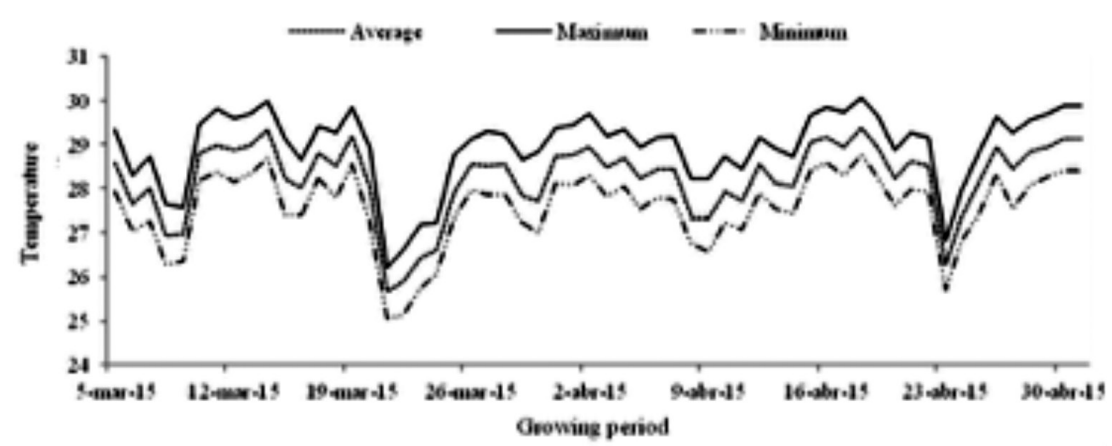

Figure 1. Minimum, medium and maximum daily temperature during the experimental period.

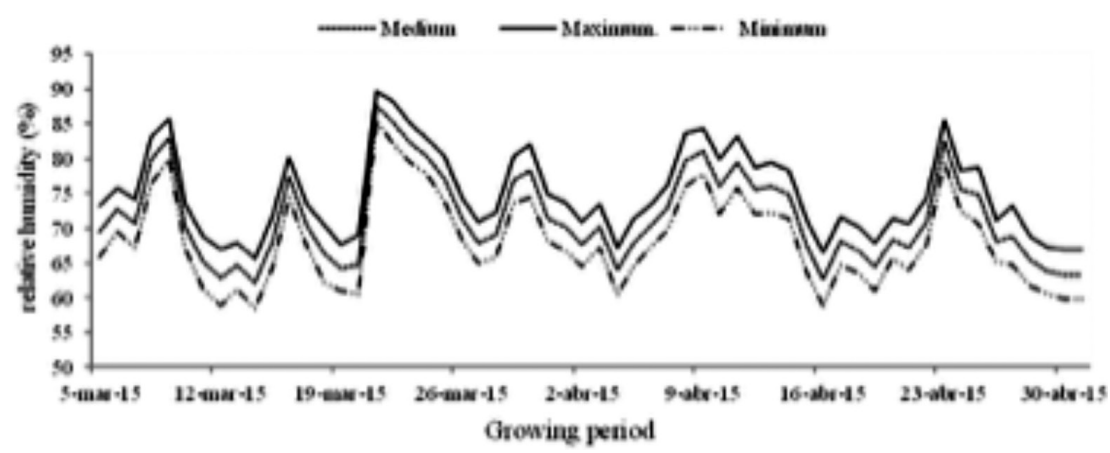

Figure 2. Minimum, medium and maximum daily relative humidity during the experimental period. 
The experimental design was randomized blocks, with 5 treatments and 5 blocks, totaling 25 experimental plots. The treatments consisted of five concentrations of macronutrients $(\mathrm{N}, \mathrm{P}, \mathrm{K} ; \mathrm{Ca}$, $\mathrm{Mg}$ and $\mathrm{S}$ ) in the standard nutrient solution: $\mathrm{C}_{2}=$ $75 \%, \mathrm{C}_{3}=50 \%, \mathrm{C}_{4}=25 \%$ and $\mathrm{C}_{5}=12.5 \%$ and $\mathrm{C}_{1}$ $=100 \%$ of the standard solution for the melon crop proposed by Furlani et al. (1999). The composition of nutrients used in the nutrient solutions of the melon crop are presented in Table 1.

The nutrient solutions were composed of commercial fertilizer salts for the macronutrients and analytical reagents for the micronutrients (Table 2). The concentrations of the nutrient solutions were obtained from the dilutions of the standard solution in water from the municipal water supply system to compose the treatments. The nutrient solutions were renewed weekly to maintain the initial concentration of the treatments. After the addition of macro- and micronutrients in the nutrient solution, its electrical conductivity ( $\mathrm{EC}$, in $\mathrm{dS} \mathrm{m}^{-1}$ ) was monitored; $\mathrm{pH}$ was always maintained in the range from 5.5 to 6.6.

The nutrient solution was applied by an automatic irrigation system with one emitter per plant (microtubes with $\varnothing=1 \mathrm{~mm}$ ). Six daily irrigations were applied to maintain the substrate in the pots at the maximum water storage capacity. The nutrient supply system was cut when drainage

Table 1. Composition of the nutrient solutions of the treatments based on the standard solution.

\begin{tabular}{|c|c|c|c|c|c|c|c|c|c|c|c|c|}
\hline \multirow{2}{*}{$\begin{array}{c}\text { Concentrations } \\
(\%)\end{array}$} & $\mathrm{N}$ & K & $\mathrm{P}$ & $\mathrm{Ca}$ & $\mathrm{Mg}$ & S & B & $\mathrm{Cu}$ & $\mathrm{Mn}$ & Mo & $\mathrm{Zn}$ & $\mathrm{Fe}$ \\
\hline & \multicolumn{12}{|c|}{$\mathrm{mg} \mathrm{L}^{-1}$} \\
\hline 100 & 210.5 & 270 & 50 & 170 & 40 & 52 & 0.5 & 0.1 & 0.5 & 0.05 & 0.3 & 2.2 \\
\hline 75 & 157.9 & 202.5 & 37.5 & 127.5 & 30.0 & 39.0 & 0.5 & 0.1 & 0.5 & 0.05 & 0.3 & 2.2 \\
\hline 50 & 105.3 & 135.0 & 25.0 & 85.0 & 20.0 & 26.0 & 0.5 & 0.1 & 0.5 & 0.05 & 0.3 & 2.2 \\
\hline 25 & 52.6 & 67.5 & 12.5 & 42.5 & 10.0 & 13.0 & 0.5 & 0.1 & 0.5 & 0.05 & 0.3 & 2.2 \\
\hline 12.5 & 26.3 & 33.8 & 6.3 & 21.3 & 5.0 & 6.5 & 0.5 & 0.1 & 0.5 & 0.05 & 0.3 & 2.2 \\
\hline
\end{tabular}

Table 2. Quantities of fertilizers and reagents used to compose the nutrient solutions.

\begin{tabular}{|c|c|c|c|c|c|c|c|}
\hline \multirow{3}{*}{\multicolumn{2}{|c|}{ Fertilizers and reagents }} & & \multicolumn{5}{|c|}{ Concentrations (\%) } \\
\hline & & & 100 & 75 & 50 & 25 & 12.5 \\
\hline & & & \multicolumn{5}{|c|}{ Amount (g $\left.100 \mathrm{~L}^{-1}\right)$} \\
\hline \multirow{4}{*}{ Macronutrients } & Calcium nitrate & $\begin{array}{c}\mathrm{Ca}-19 \% \\
\mathrm{~N}-\mathrm{NO}_{3}-14.5 \% \\
\mathrm{~N}-\mathrm{NH}_{4}-1.0 \%\end{array}$ & 89.500 & 67.125 & 44.750 & 22.375 & 8.391 \\
\hline & Potassium nitrate & $\begin{array}{c}\mathrm{K}-36.5 \% \\
\mathrm{~N}-\mathrm{NO}_{3}-13.0 \% \\
\end{array}$ & 74.000 & 55.500 & 37.000 & 18.500 & 6.938 \\
\hline & $\begin{array}{l}\text { Purified monoammonium } \\
\text { phosphate (MAP) }\end{array}$ & $\begin{array}{c}\mathrm{N}-\mathrm{NH}_{4}-11.0 \% \\
\mathrm{P}-26 \%\end{array}$ & 19.200 & 14.400 & 9.600 & 4.800 & 1.800 \\
\hline & Magnesium sulfate & $\begin{array}{c}\mathrm{Mg}-10.0 \% \\
\mathrm{~S}-13.0 \%\end{array}$ & 40.000 & 30.000 & 20.000 & 10.000 & 3.750 \\
\hline \multirow{6}{*}{ Micronutrients } & Copper sulfate & $\mathrm{Cu}-13 \%$ & 0.077 & 0.077 & 0.077 & 0.077 & 0.077 \\
\hline & Zinc sulfate & $\mathrm{Zn}-22 \%$ & 0.135 & 0.135 & 0.135 & 0.135 & 0.135 \\
\hline & Manganese sulfate & Mn $-26 \%$ & 0.190 & 0.190 & 0.190 & 0.190 & 0.190 \\
\hline & Boric acid & B $-17 \%$ & 0.059 & 0.059 & 0.059 & 0.059 & 0.059 \\
\hline & Sodium molybdate & Мо - $39 \%$ & 0.013 & 0.013 & 0.013 & 0.013 & 0.013 \\
\hline & Fe-EDTA & $\mathrm{Fe}-13 \%$ & 1.694 & 1.694 & 1.694 & 1.694 & 1.694 \\
\hline
\end{tabular}


occurred, and subsequently the drained nutrient solution, stored in a 0.5 - $\mathrm{L}$ container installed in each pot, was recirculated to the pot.

The seedlings of 'Gália' melon (hybrid 'Babilônia RZ F' - Rijk Zwaan®) were produced on polystyrene trays with 128 cells containing coconut fiber substrate and manually irrigated with tap water.

After transplantation, the melon plants were trained vertically using a single stake with raffia ribbon fixed to a wire at height of about $2.0 \mathrm{~m}$ above the cultivation line. The other cultivation and phytosanitary practices were performed as necessary, according to alternative and conventional methods. The basal secondary branches with height of up to approximately $20 \mathrm{~cm}$ were eliminated, leaving only the main branch. Pruning was performed weekly to eliminate lateral sprouts, leaving only the sprouts intended for fruit development, which were subsequently cut at the first leaf after the fruit.

Pollination was performed manually in the first hours of the morning 35 days after germination. After fruit setting, thinning was performed leaving 2 fruits per plant. The phytosanitary control was made based on technical recommendations, through preventive and control applications, with pesticides every seven days on average, and always when necessary.

The fruits were harvested 60 days after transplantation (DAT) for the analyses of the parameters of production and post-harvest physicochemical quality: mean fruit weight, longitudinal and transverse fruit diameters, fruit shape index, relationship between shape and the internal transverse and longitudinal cavities of the fruit, rind and pulp thickness, pulp firmness, soluble solids, Titratable acidity, juice $\mathrm{pH}$, maturation index.

The data obtained were subjected to analysis of variance and polynomial regression using the program Assistat $₫$, and Microsoft Excel ${ }^{\circledR}$ to build the graphs.

\section{Results and discussion}

\section{Fruit production}

According to the analysis of variance, there was a significant quadratic effect $(p<0.01)$ of the concentrations on the variables mean fruit weight, fruit production and yield (Table 3). Mean weight of the melon fruits reached its maximum of $632.58 \mathrm{~g}$ plant ${ }^{-1}$ for a nutrient solution concentration estimated at $47 \%$; therefore, it is close to concentration $\mathrm{C}_{3}$ $(50 \%)$, with reduction of the mean weight from this concentration on (Figure 3). The lowest mean fruit weight $\left(503.89 \mathrm{~g} \mathrm{plant}^{-1}\right)$ was observed in the plots of the treatments fertigated with the concentration of $100 \%$ standard solution, with reduction of $20.34 \%$ in mean fruit weight in relation to the maximum estimated value. These values were lower than those obtained by Mascarenhas et al. (2010), who found mean values from 880 to $960 \mathrm{~g}$ in 'Néctar' hybrid melon.

The reduction in mean fruit weight with the increase in the nutrient solution concentration observed in the present study may be related to the high salinity of the substrate, caused by the gradual

Table 3. Summary of the analysis of variance for mean fruit weight (MFW), fruit production (FP) and yield (Y) of 'Gália' melon, as a function of the different concentrations of the nutrient solution.

\begin{tabular}{|c|c|c|c|c|}
\hline \multirow{2}{*}{ SV } & \multirow{2}{*}{ DF } & \multicolumn{3}{|c|}{ Mean square } \\
\hline & & MFW & FY & $\mathrm{Y}$ \\
\hline Concentrations & 4 & $15204.26^{* *}$ & $60817.034 * *$ & $380106.7563^{* *}$ \\
\hline Blocks & 4 & $164.56344^{\mathrm{ns}}$ & $658.25339^{\mathrm{ns}}$ & $4114.11423^{\mathrm{ns}}$ \\
\hline Linear model & 1 & $11205.15578^{*}$ & $44820.59916^{*}$ & $280129.41841^{*}$ \\
\hline Quadratic model & 1 & $42849.12099 * *$ & $171396.44437 * *$ & $1071228.14842 * *$ \\
\hline Cubic model & 1 & $6157.05726^{\mathrm{ns}}$ & $24628.19353^{\mathrm{ns}}$ & $153926.37604^{\mathrm{ns}}$ \\
\hline Error & 16 & 1366.482 & 5465.9311 & 34162.06788 \\
\hline Total & 24 & & & \\
\hline $\mathrm{CV} \%$ & & 6.33 & 6.33 & 6.33 \\
\hline
\end{tabular}




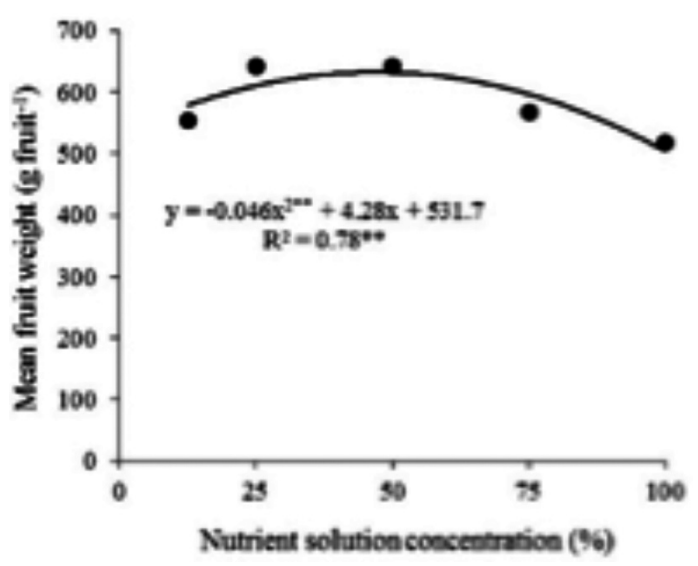

Figure 3. Mean fruit weight as a function of the nutrient solution concentration.

accumulation of the applied fertilizer salts, which reached $2.2 \mathrm{dS} \mathrm{m}^{-1}$ at $45 \mathrm{DAT}$ and $3.1 \mathrm{dS} \mathrm{m}^{-1}$ at 60 DAT for the concentration $\mathrm{C}_{1}$.

Considering that the 'Gália' melon packing box for exportation generally has a capacity for 5 $\mathrm{kg}$, holding 4 to 9 fruits (EMBRAPA, 2010) and the minimum fruit weight for exportation of $555 \mathrm{~g}$ (Filgueiras et al., 2000), from the concentration of $12.5 \%$ up to $88 \%$, the produced fruits had the minimum size for exportation.

Purquerio et al. (2003) grew 'Bônus n' 2' melon in NFT hydroponic system and observed that the increase of $\mathrm{N}$ concentration in the nutrient solution reduced the mean weight of the fruits. The authors obtained mean weights of 675,655 and $624 \mathrm{~g}_{\text {fruit }}{ }^{-1}$, at $\mathrm{N}$ concentrations of 237,248 and $300 \mathrm{mg} \mathrm{L}^{-1}$, respectively.

Dias et al. (2011) observed reduction in the relative yield of melon grown in coconut fiber under different phases of exposure to the salinity of the nutrient solution. These authors reported reductions of 7.10, 5.70 and $9.7 \%$ per unit increase in the solution EC for the exposure periods of 10-30, 31-50 and 51-70 DAT, respectively. The authors concluded that the observed relative reductions are due to the effects of the nutrient solution osmotic potential on the melon plants cultivated in a hydroponic system.

For 'Gália' melon (hybrid 'Néctar') cultivated in soil, Melo et al. (2011) established the ECw of $1.48 \mathrm{dS} \mathrm{m}^{-1}$ as the limit capable of producing minimum relative yield of $90 \%$. Dias et al. (2010) grew 'Cantaloupe' melon in a hydroponic system with coconut fiber and observed threshold salinity of the melon crop for mean fruit weight of $1.66 \mathrm{dS} \mathrm{m}^{-1}$ and relative loss of $7.48 \%$ per $\mathrm{dS} \mathrm{m}^{-1}$.

There was a quadratic effect on mean fruit production and yield, with values of fruit production and total yield of $1265.12 \mathrm{~g} \mathrm{plant}^{-1}$ and $3,171.70 \mathrm{~g} \mathrm{~m}^{2}$ for a concentration of $47 \%$ of the standard solution (Figure $4 \mathrm{a}$ and $\mathrm{b}$ ).

The climate condition also influenced the reduction of fruit weight and mean yield observed in the present study because rainfall occurred during the experimental period, with increase in relative air humidity (Figure 3). Conditions of relative air humidity above $75 \%$ lead to the formation of lowquality fruits and presence of diseases in the crop (EMBRAPA, 2010).

\section{Fruit quality}

Based on the analysis of variance, the concentrations of the nutrient solutions significantly influenced all analyzed quality parameters except fruit shape index. There was a quadratic effect of the nutrient solution concentration on the parameters (a)

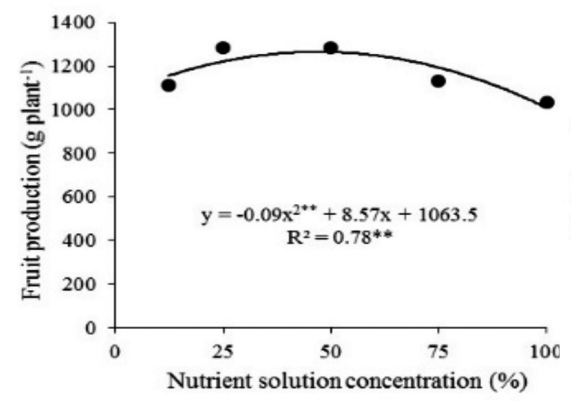

(b)

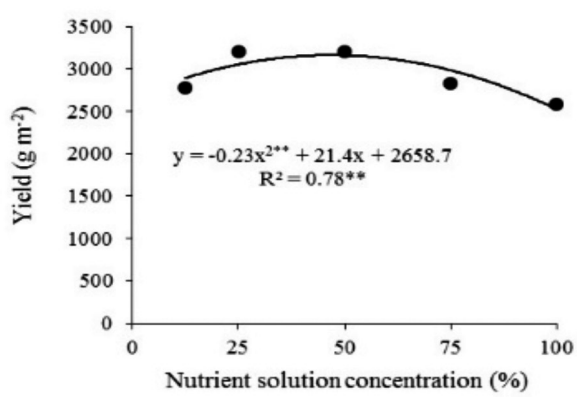

Figure 4. Fruit production (a) and yield (b) as a function of the nutrient solution concentration. 
fruit longitudinal diameter, transverse diameter, transverse cavity and pulp thickness, and linear effect on the parameters longitudinal cavity and pulp firmness (Table 4).

The maximum value of TD was obtained at a concentration of $39 \%(10.66 \mathrm{~cm})$, while the LD was $11.16 \mathrm{~cm}$, obtained at the concentration of $37 \%$ (Figure 5). These values are close to those observed by Rocha et al. (2010) for 'Gália' melon (hybrid 'Solar King'), equal to $11.96 \mathrm{~cm}$ of TD and $12.91 \mathrm{~cm}$ of LD. Purquerio \& Cecílio Filho (2005), in 'Bônus $\mathrm{n}^{\circ}$ 2' melon hybrids in NFT cultivation, observed reductions in the longitudinal and transverse diameters of the fruits with the increase of $\mathrm{N}$ concentration in the nutrient solution.

The fruit shape index (FSI) did not have significant fit to any mathematical model, showing a mean value of 1.04. According to the FSI classification proposed by Morais et al. (2004), the fruits of the present study are spherical. Rocha et al. (2010) also obtained fruits of 'Gália' melon classified as spherical, but with FSI slightly higher than those of the present study (1.08). Pádua et al. (2003) claim that all shapes are accepted by the market, but spherical fruits are the most adequate for arrangement in packages and for transport.

The transverse cavity of the fruit (TC) fitted to a decreasing linear model with the increase in the nutrient solution concentration (Figure 6a). The obtained TC values ranged from 4.14 to 4.64 , from the highest to the lowest nutrient solution concentration. Nunes et al. (2004) obtained higher values of internal cavity for six hybrids of 'Gália' melon cultivated in soil, with mean value of $5.94 \mathrm{~cm}$.

The longitudinal cavity (LC) fitted a cubic model, with highest value $(8.40 \mathrm{~cm})$ at a concentration of $35 \%$ (Figure 6b). According to Charlo et al. (2009), the internal cavity of the fruit is a characteristic that is genetically defined and little influenced by the environment, which must be taken into consideration, because the lower the diameter of the locus, the greater the resistance of the fruit to transport, thus improving its conservation.

Rind thickness (RT) showed a cubic response (Figure 7a). The lowest value was obtained at the concentration $\mathrm{C}_{5}(0.42 \mathrm{~cm})$. From this point on, there was an increase due to the increment in the nutrient solution concentration until concentration $\mathrm{C}_{4}$, remaining between 0.5 and $0.6 \mathrm{~cm}$ until $\mathrm{C}_{2}$, where it tended to increase again up to the maximum value of $0.83 \mathrm{~cm}$ in $\mathrm{C}_{1}$.

There was a general trend for fruits with thicker rind as the amount of fertilizer applied to the plant increased. These values are consistent with those obtained by Folegatti et al. (2004), who reported RT between 0.485 and $0.758 \mathrm{~cm}$ for netted melon, cultivar 'Bônus II'.

For pulp thickness (PT) the behavior was quadratic, with maximum value of $2.9 \mathrm{~cm}$ at a concentration of $42 \%$ (Figure $7 b$ ). Similar PT values, between 2.55 and $3.38 \mathrm{~cm}$, were obtained by Nunes et al. (2004) for six hybrids of 'Gália' melon cultivated in the Mossoró-Assu agricultural center, and also by Folegatti et al. (2004), who observed means between 2.82 and $3.77 \mathrm{~cm}$ for

Table 4. Analysis of variance (ANOVA) for longitudinal diameter (LD), transverse diameter (TD), fruit shape index (FSI), transverse cavity (TC), longitudinal cavity (LC), pulp thickness (PT), rind thickness (RT) and pulp firmness (PF) of 'Gália' melon (hybrid 'Babilônia RZ F1') as a function of different concentrations of the nutrient solution.

\begin{tabular}{|c|c|c|c|c|c|c|c|c|c|}
\hline \multirow{2}{*}{ SV } & \multirow{2}{*}{ DF } & \multicolumn{8}{|c|}{ Mean square } \\
\hline & & LD & TD & FSI & $\mathrm{TC}$ & $\mathrm{LC}$ & PT & ST & FP \\
\hline Concentrations & 4 & $0.84165^{*}$ & $0.6343 *$ & $0.00011^{\mathrm{ns}}$ & $0.295^{* *}$ & $0.6624 *$ & $0.18658 *$ & $0.10871 * *$ & $11.74706^{* *}$ \\
\hline Blocks & 4 & $0.19490^{\mathrm{ns}}$ & $0.38178^{\mathrm{ns}}$ & $0.00203^{\mathrm{ns}}$ & $0.1550 *$ & $0.1142^{\mathrm{ns}}$ & $0.03640^{\mathrm{ns}}$ & $0.02053 *$ & $2.65016^{\mathrm{ns}}$ \\
\hline Linear model & 1 & $1.23245^{*}$ & $0.93025^{*}$ & $0.00003^{\mathrm{ns}}$ & $0.8192 * *$ & $0.4024 \mathrm{~ns}$ & $0.22302 *$ & $0.29316^{* *}$ & $37.73516^{* *}$ \\
\hline Quadratic model & 1 & $1.04432 *$ & $0.96526^{*}$ & $0.00010^{\mathrm{ns}}$ & $0.0051^{\mathrm{ns}}$ & $0.9339^{*}$ & $0.24477 *$ & $0.00024^{\mathrm{ns}}$ & $0.48910^{\mathrm{ns}}$ \\
\hline Cubic model & 1 & $0.76880^{\mathrm{ns}}$ & $0.38544^{\mathrm{ns}}$ & $0.00023^{\mathrm{ns}}$ & $0.0840^{\mathrm{ns}}$ & $1.1924 *$ & $0.10613^{\mathrm{ns}}$ & $0.13446^{* *}$ & $1.31447^{\mathrm{ns}}$ \\
\hline Error & 16 & 0.19146 & 0.16491 & 0.00059 & 0.0437 & 0.1553 & 0.02914 & 0.00584 & 3.52001 \\
\hline Total & 24 & & & & & & & & \\
\hline $\mathrm{CV} \%$ & & 4.01 & 3.90 & 2.31 & 4.74 & 5.04 & 6.25 & 13.72 & 13.49 \\
\hline
\end{tabular}

$* *=$ significant at the $1 \%$ level of probability $(\mathrm{p}<0.01) ; *$ significant at the $5 \%$ de level of probability $(0.01 \leq \mathrm{p}<0.05) ;{ }^{\mathrm{ns}}=\mathrm{not}$ significant $(\mathrm{p}>=0.05)$. SV= Source variation; $\mathrm{DF}=$ Degrees of freedom; $\mathrm{CV}=$ Coefficient of variation. 
(a)

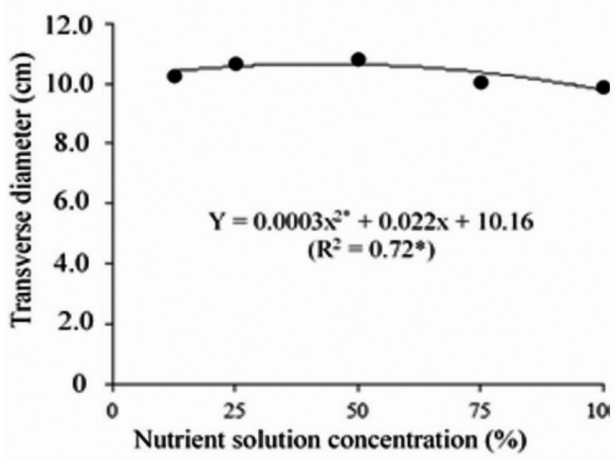

(b)

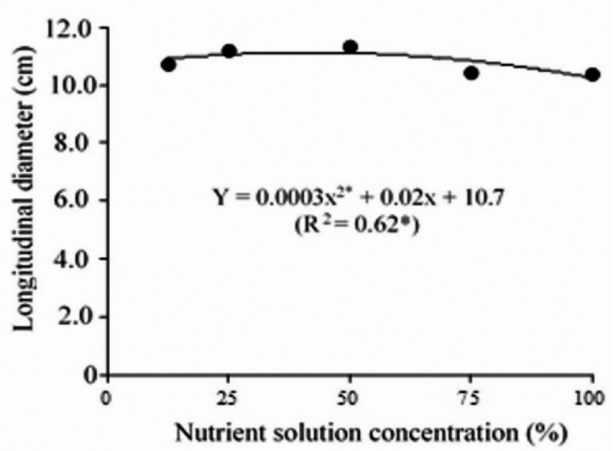

Figure 5. Transverse diameter (a) and longitudinal diameter (b) of the fruit as a function of the nutrient solution concentration.

(a

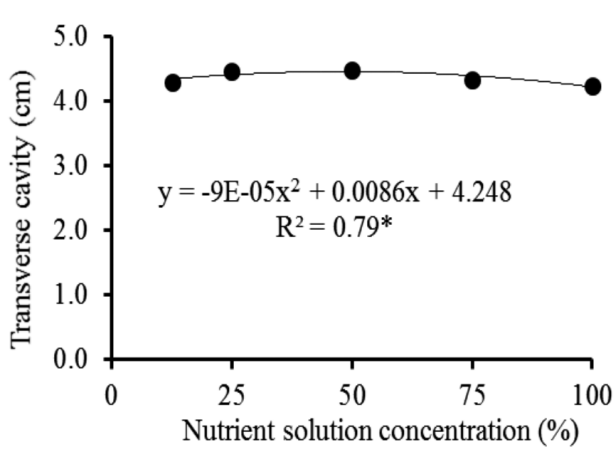

(b

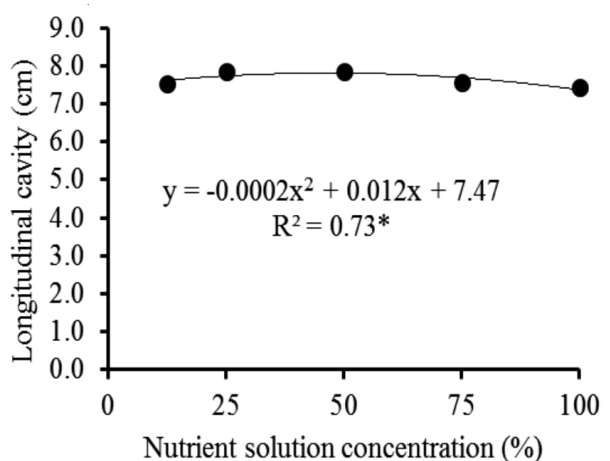

Figure 6. Transverse cavity (a) and longitudinal cavity (b) of the fruit as a function of the nutrient solution concentration.

(a)

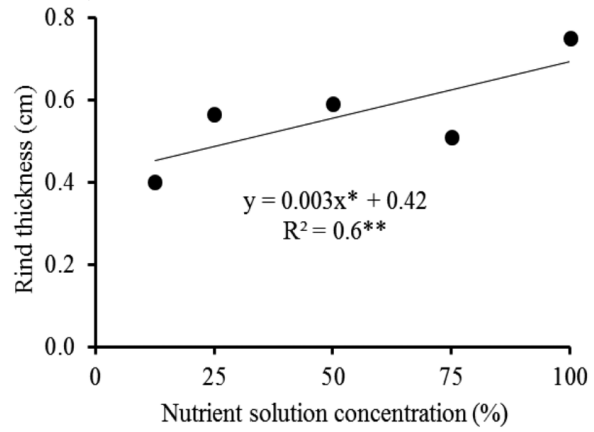

(b)

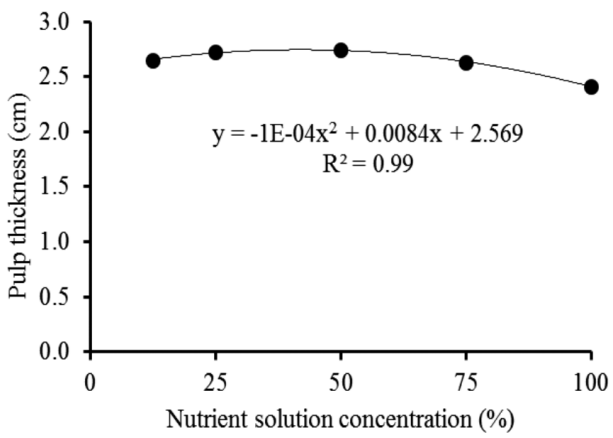

Figure 7. Rind thickness (a) and pulp thickness (b) of the fruit as a function of the nutrient solution concentration.

various irrigation depths and doses of potassium in the melon crop.

Morais et al. (2004), working with 'Gália' melon hybrids, observed pulp thickness varying from
3.07 to $3.92 \mathrm{~cm}$. Purquerio \& Cecílio Filho (2005) observed reduction of $6.9 \%$ in melon pulp thickness with the increment of $\mathrm{N}$ dose in the nutrient solution from 80 to $300 \mathrm{mg} \mathrm{L}^{-1}$. According to Purquerio 
et al. (2003), the reductions of TD, LD and PT are responsible for the reduction in fruit weight, and consequently yield, which also decreased with the increment in the $\mathrm{N}$ concentration in the solution.

Pulp firmness $(\mathrm{PF})$ reduced linearly with the increment in the nutrient solution concentration (Figure 8). The highest value (15.23 N) was obtained for the concentration of $12.5 \%$ and the lowest (12.05 $\mathrm{N})$ for $100 \%$. These values are below the range of 22 $\mathrm{N}$ to $30 \mathrm{~N}$ recommended by Filgueiras et al. (2000) for 'Gália' melons intended for the external market. Folegatti et al. (2004) reported values of pulp firmness (PF) ranging from 4.45 to $17.51 \mathrm{~N}$ in the cultivation of 'Bônus II' netted melon. Pulp firmness is an important quality attribute, because firm fruits are more resistant to mechanical injuries during transport and commercialization. Fruits harvested with higher pulp firmness usually have greater conservation and post-harvest life (Tomaz et al., 2009).

Table 5 shows the summary of the analysis of variance for soluble solids (SS), titratable acidity (TA), pulp $\mathrm{pH}(\mathrm{pH})$, total sugars (TSug) and maturation index (MI). There was significant effect of concentration only on $\mathrm{pH}$. In the regression analysis, there was linear effect only on SS, pH and MI.

The content of soluble solids (SS) decreased linearly $(\mathrm{p}<0.05)$ with the increment in nutrient solution concentration (Figure 9). The obtained values varied from 11.07 to $9.03{ }^{\circ} \mathrm{Brix}$, from the concentration of $12.5 \%$ to $100 \%$, respectively. These values are below the minimum SS content, $12^{\circ} \mathrm{Brix}$, recommended by Filgueiras et al. (2000) for 'Gália' melons intended for the external market. However,

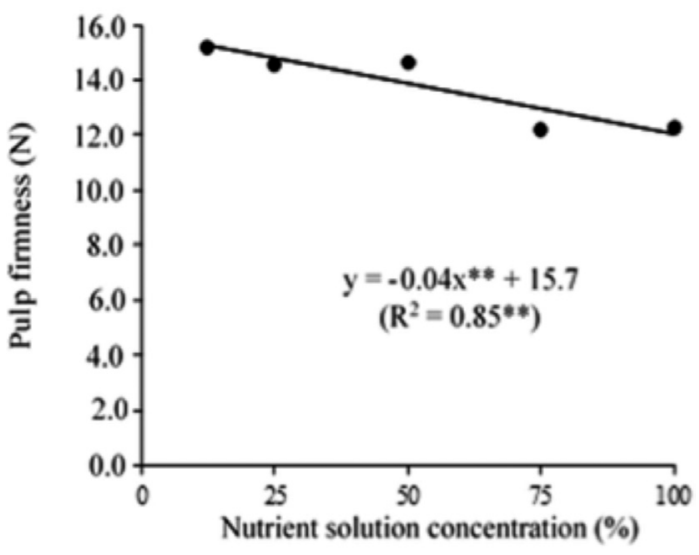

Figure 8. Pulp firmness of the fruit as a function of the nutrient solution concentration.

these same authors emphasize that at least $9{ }^{\circ} \mathrm{Brix}$ of soluble solids is established as minimum quality requisite for the melon crop.

These values are close to those obtained by Aroucha et al. (2009), who evaluated the quality and post-harvest potential of 'Gália' melon hybrids and obtained SS values from 10.95 to $12.28^{\circ}$ Brix, and above the initial SS values reported by Morais et al. (2004), equal to $8.8,8.9,9.1$ and $9.4^{\circ}$ Brix for the 'Gália' melon hybrids 'Primal', 'Vicar', 'Total' and 'Solarking', respectively. According to Lester \& Turley (1990), the selection of melon fruits by consumers first occurs based on their sugar content, which is considered as the main qualitative aspect, then on the aroma and color of the pulp, and lastly on their consistency or firmness.

Table 5. Summary of the analysis of variance for soluble solids (SS), titratable acidity (TA), pulp pH (pH), total sugars (TSug) and maturation index (MI) of 'Gália' melon, hybrid 'Babilônia RZ F1', as a function of different nutrient solution concentrations.

\begin{tabular}{|c|c|c|c|c|c|c|}
\hline \multirow{2}{*}{ SV } & \multirow{2}{*}{ DF } & \multicolumn{5}{|c|}{ Mean square } \\
\hline & & SS & TA & $\mathrm{pH}$ & $\mathrm{TS}$ & MI \\
\hline Concentrations & 4 & $3.68725^{\mathrm{ns}}$ & $0.00097^{\mathrm{ns}}$ & $0.10883^{*}$ & $2.03220^{\mathrm{ns}}$ & $661.9806^{\mathrm{ns}}$ \\
\hline Blocks & 4 & $1.40100^{\mathrm{ns}}$ & $0.00043^{\mathrm{ns}}$ & $0.04257^{\mathrm{ns}}$ & $1.96101^{\mathrm{ns}}$ & $217.24211^{\mathrm{ns}}$ \\
\hline Linear model & 1 & $13.83380 *$ & $0.00111^{\mathrm{ns}}$ & $0.18666^{*}$ & $3.72323^{\mathrm{ns}}$ & $1567.89371 *$ \\
\hline Quadratic model & 1 & $0.00129^{\mathrm{ns}}$ & $0.00019^{\mathrm{ns}}$ & $0.05460^{\mathrm{ns}}$ & $4.08286^{\mathrm{ns}}$ & $119.93061^{\mathrm{ns}}$ \\
\hline Cubic model & 1 & $0.08820^{\mathrm{ns}}$ & $0.00050^{\mathrm{ns}}$ & $0.05346^{\mathrm{ns}}$ & $0.09031^{\mathrm{ns}}$ & $58.92426^{\mathrm{ns}}$ \\
\hline Error & 20 & 2.202 & 0.0004 & 0.02774 & 1.5307 & 258.76679 \\
\hline Total & 24 & & & & & \\
\hline $\mathrm{CV} \%$ & & 14.63 & 14.58 & 2.37 & 12.11 & 21.18 \\
\hline
\end{tabular}




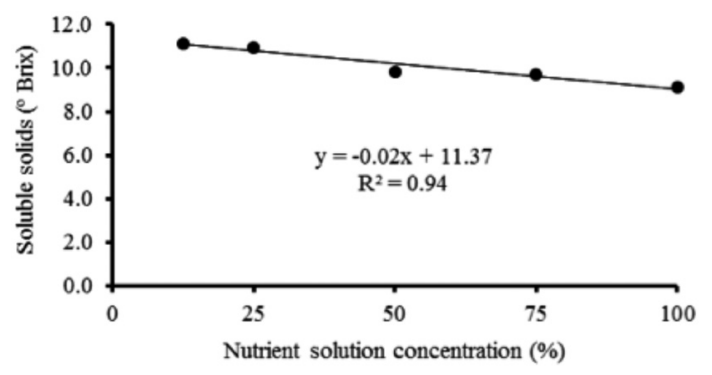

Figure 9. Content of soluble solids of the fruit as a function of the nutrient solution concentration.

The titratable acidity did not show significant fit to any mathematical model, exhibiting a mean value of $0.1375 \mathrm{~g}$ of citric acid per 100 $\mathrm{mL}$ of juice. A different behavior was reported by Purquerio and Cecílio Filho (2005), who observed that for the first and third fruits of the melon plant, hybrid 'Bônus $\mathrm{n}^{\circ} 2^{2}$ ', cultivated in NFT hydroponic system, acidity increased linearly with the increment of $\mathrm{N}$ in the nutrient solution, reaching 0.128 and $0.132 \mathrm{~g}$ of citric acid per 100 $\mathrm{mL}$ of juice, respectively.

Vargas et al. (2008) obtained from 0.09 to $0.13 \%$ citric acid for cultivars of netted melon. In most fruits acidity represents one of the main components of the flavor, because their acceptance depends on the balance between acids and sugars, and the preference is for high contents of these constituents. In melon, the variation in acidity levels has little meaning due to the low concentration, and the interference of acidity in the taste is not very representative (Morais et al., 2009).

Pulp pH increased linearly with the increment in the concentration of nutrients (Figure 10), but the observed values showed small variation, from 6.92 to 7.15 from the lowest to the highest concentration. Morais et al. (2009) reported pulp $\mathrm{pH}$ results ranging from 6 to 7, close to those of the present study.

The data of total sugars did not fit to polynomial models. The mean value was $10.22 \%$, which is above the mean values presented by Morais et al. (2009), equal to 7.7, 7.2, 8.7 and 7.5 for the 'Gália' melons 'Solar King', Cantaloupe 'Torreon', Charentais 'Aura Prince' and Orange flesh 'AF1749', respectively.

The maturation index decreased linearly with the increment in the nutrient solution concentration
(Figure 11). The highest value (85.65) occurred at the concentration $\mathrm{C}_{5}(12.5 \%)$, while the lowest value (68.92) occurred at the concentration $\mathrm{C}_{1}$ (100\%). Vargas et al. (2008) obtained maturation index from 69.17 to 126.00 for five cultivars of netted melon.

\section{Conclusions}

Mean fruit weight, longitudinal diameter and transverse diameter were quadratically influenced by the nutrient solution concentrations.

The concentration of $47 \%$ led to the highest value of mean fruit weight.

The increase in the nutrient solution concentration reduced by $11.8 \%$ the content of soluble solids of the fruit.

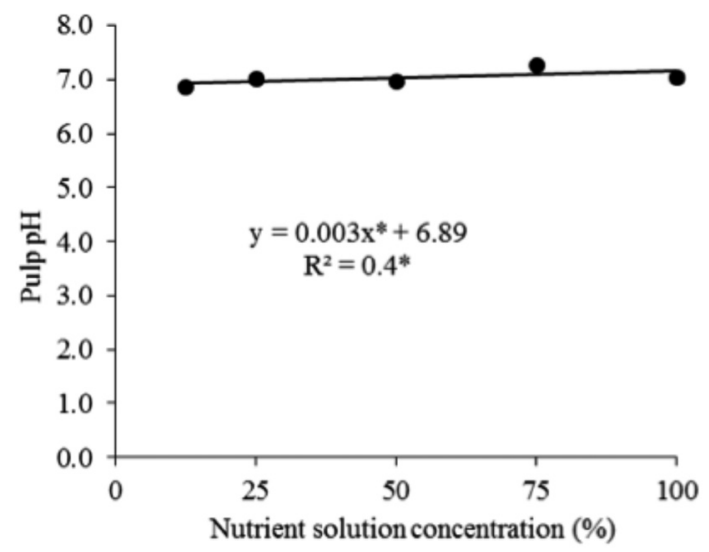

Figure 10. Fruit pulp pH as a function of the nutrient solution concentration.

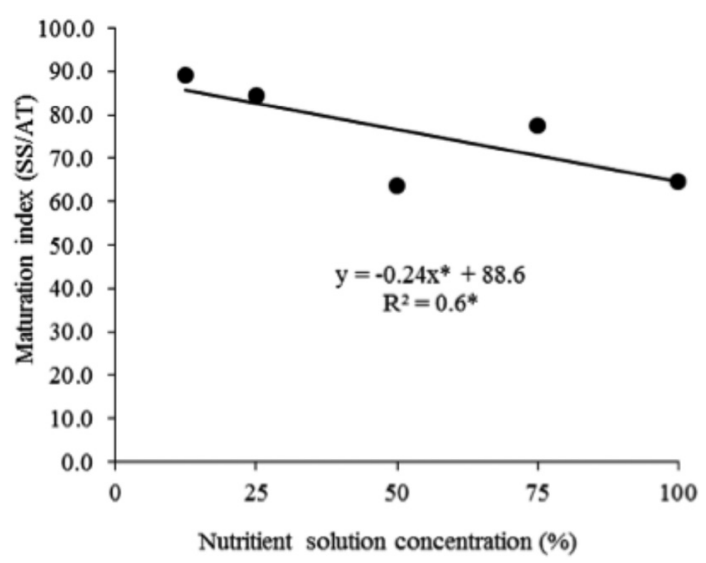

Figure 11. Maturation index of the fruit as a function of the nutrient solution concentration. 


\section{Literature Cited}

Aroucha, E.M.M.; Nunes, G.H.S.; Sousa, A.E.D.; Fernandes, P.L.O.; Souza, M.Z.

2009. Qualidade e potencial pós-colheita de híbridos de melão. Revista Ceres, 56 (2): 181-185.

Cardoso, A.F.; Charlo, H.C.O.; Ito, L.A.; Braz, L.T.; Corá, J. E. 2009. Produção de híbridos de melão rendilhado em função da reutilização do substrato. Horticultura Brasileira, 27 (2): 2653-2657.

Charlo, H.C.O.; Castoldi, L.; Vargas, P.F.; Braz, L.T.

2009. Desempenho de híbridos de melão-rendilhado cultivados em substrato. Científica, 37 (1): 16-21.

Damasceno, A.P.A.B.; Medeiros, J.F.; Medeiros, D.C.; Melo, I.G.C.; Dantas, D.C.

2012. Crescimento e marcha de absorção de nutrientes do melão Cantaloupe tipo "harper" fertirrigado com doses de N e K. Revista Caatinga, 25 (1): 137-146.

Dias, N.S.; Lira, R.B.; Brito, R.F.; Sousa Neto, O.N.; Ferreira

Neto, M.; Oliveira, A.M.

2010. Produção de melão rendilhado em sistema hidropônico com rejeito da dessalinização de água em solução nutritiva. Revista Brasileira de Engenharia Agrícola e Ambiental, 14 (7): 755-761.

Dias, N.S.; Duarte, S.N.; Medeiros, J.F.; Teles Filho, J.F.

2006. Salinidade e manejo da fertirrigação em ambiente protegido. II: Efeitos sobre o rendimento do meloeiro. Irriga, 11 (3): 376-383.

Dias, N.S.; Oliveira, A.M.; Sousa Neto, O.N.; Blanco, F.F.; Rebolças, J.R.L.

2011. Concentração salina e fases de exposição à salinidade do meloeiro cultivado em substrato de fibra de coco. Revista Brasileira de Fruticultura, 33 (3): 915-921.

Embrapa.

2010. Sistema de produção de melão. Avaiable in: <https://www. spo.cnptia.embrapa.br/conteudo?p_p_id=conteudoportlet_ WAR_sistemasdeproducaolf6_1ga1ceportlet\&p_p_ lifecycle $=0 \&$ p_p_state $=$ normal\&p_p_mode $=$ view\&p_p_ col_id=column-1\&p_p_col_count=1\&p_r_p_-76293187_ sistemaProducaoId=4103\&p_r_p_-996514994_ topicoId $=4249>$. Access in: 12/Jan/2015.

Filgueiras, H.A.C.; Menezes, J.B.; Alves, R.E.; Costa, F.V.;

Pereira, L.S.E.; Gomes Júnior, J.

2000. Colheita e manuseio pós-colheita. In: Alves, R. E. (Org). Melão pós-colheita. EMBRAPA-SPI, 2000. Brasília, Brazil. p. 23-41.

Folegatti, M.; Vásquez, M.A.N.; Dias, N.S.; Sousa, V.F. 2004. Qualidade física do melão fertirrigado com diferentes dosagens de potássio e lâminas de irrigação, em gotejamentos superficial e subsuperficial. Irriga, 9 (1): 52-61.

Furlani, P.R.; Silveira, L.C.P., Bolonhezi, D.; Faquin, V. 1999. Cultivo hidropônico de plantas. Campinas: IAC. (Boletim técnico,180).

IBGE. Instituto Brasileiro de Geografia e Estatística.

2014. Produção agrícola municipal. 41, 1-95. Avaiable in: $<$ https://biblioteca.ibge.gov.br/visualizacao/periodicos/66/ pam_2014_v41_br.pdf $>$. Access in: 24/Jan/2017.

Lester, G.E.; Turley, R.M.

1990. Chemical, physical and sensory comparisons of netted muskmelon fruit cultivars and breeding lines at harvest. Journal Rio Grande Valley Horticultural Society, 43: 71-77.

Mascarenhas, F.R.; Medeiros, D.C.; Medeiros, J.F.; Dias, P.M.S.; Souza, M.S.M.

2010. Produção e qualidade de melão Gália cultivado sob diferentes níveis de salinidade. Revista Verde de Agroecologia e Desenvolvimento Sustentável, 5 (5): 171-181.

Medeiros, D.C.; Medeiros, J.F.; Pereira, F.A.L.; Souza, R.O.; Pahveli, A.S.

2011. Produção e qualidade de melão cantaloupe cultivado com água de diferentes níveis de salinidade. Revista Caatinga, 24 (1): 92-98.

Melo, T.K.; Medeiros, J.F.; Espínola Sobrinho, J.; Figueiredo, V.B.; Pereira, V.C.; Campos, M.S.

2011. Evapotranspiração e produção do melão Gália irrigado com água de diferentes salinidades e adubação nitrogenada. Revista Brasileira de Engenharia Agrícola e ambiental, 15 (12): 1235-1242.

Morais, P.L.D.; Menezes, J.B.; Oliveira, O.F.

2004. Potencial de vida útil pós-colheita de quatro genótipos de melão tipo Gália. Ciência e Agrotecnologia, 28 (6): 1314-1320.

Morais, P.L.D.; Silva, G.G.; Maia, E.N.; Menezes, J.B. 2009. Avaliação das tecnologias pós colheita utilizadas e da qualidade de melões nobres produzidos para exportação. Ciência e Tecnologia de Alimentos, 29 (1): 214-218.

Nunes, G.H.S.; Santos Júnior, J.J.; Andrade, F.V.; Bezerra Neto,

F.; Almeida, A.H.B.; Medeiros, D.C.

2004. Aspectos produtivos e de qualidade de híbridos de melão cultivados no agropolo Mossoró-Assu. Horticultura Brasileira, 22 (4): 744-747.

Pádua, J.G.; Braz, L.T.; Banzatto, D.A.; Gusmão, S.A.L.; Gusmão, M.T.A.

2003. Net melon cultivars productivity under different cultivation systems, during summer and winter. Acta Horticulturae, 607: 83-89.

Purquerio, L.F.V.; Cecílio Filho, A.B.; Barbosa, J.C. 2003. Efeito da concentração de nitrogênio na solução nutritiva e do número de frutos por planta sobre a produção do meloeiro. Horticultura Brasileira, 21 (2): 186-191.

Purquerio, L.F.V.; Cecílio Filho, A.B.

2005. Concentração de nitrogênio na solução nutritiva e número de frutos sobre a qualidade de frutos de melão. Horticultura Brasileira, 23 (3): 831-836.

Rocha, R.H.C.; Silva, E.O.; Salomão, L.C.C. Ventrella, M.C. 2010. Caracterização morfoanatômica do melão gália no ponto de colheita. Revista Brasileira de Fruticultura, 32 (2): 375-385.

Tomaz, H.V.Q.; Aroucha, E.M.M.; Nunes, G.H.S.; Bezerra

Neto, F.; Tomaz, H.V.Q.; Queiroz, R.F. 2009. Qualidade pós-colheita de diferentes híbridos de melão-amarelo armazenados sob refrigeração. Revista Brasileira de Fruticultura, 31 (4): 987-994.

Vargas, P.F.; Castoldi, R.; Charlo, H.C.R.; Braz, L.T. 2008. Qualidade de melão rendilhado (Cucumis melo L.) em função do sistema de cultivo. Ciência e Agrotecnologia, 32 (1): $137-142$. 